\title{
Health risk assessment of heavy metals in soils and vegetables from wastewater irrigated area, Beijing-Tianjin city cluster, China
}

\author{
Yanchun Wang ${ }^{1,2}$, Min Qiao ${ }^{1}$, Yunxia Liu ${ }^{1,3}$, Yongguan Zhu ${ }^{1,3, *}$ \\ 1. State Key Laboratory of Reginal and Urban Ecology, Research Center for Eco-Environmental Sciences, \\ Chinese Academy of Sciences, Beijing 100085, China.E-mail: wang10549@sohu.com \\ 2. Beijing Institute of Landscape Architecture, Beijing 100102, China \\ 3. Key Laboratory of Urban Environment, Health Institute of Urban Environment, Chinese Academy of Science, Xiamen 361021, China
}

Received 08 June 2011; revised 01 August 2011; accepted 31 August 2011

\begin{abstract}
The possible health risks of heavy metals contamination to local population through food chain were evaluated in Beijing and Tianjin city cluster, China, where have a long history of sewage irrigation. The transfer factors (TF) for heavy metals from soil to vegetables for six elements including $\mathrm{Cu}, \mathrm{Zn}, \mathrm{Pb}, \mathrm{Cr}$, As and $\mathrm{Cd}$ were calculated and the pollution load indexes (PLI) were also assessed. Results indicate that only $\mathrm{Cd}$ exceeded the maximum acceptable limit in these sites. So far, the heavy metal concentrations in soils and vegetables were all below the permissible limits set by the Ministry of Environmental Protection of China and World Health Organization. The transfer factors of six heavy metals showed the trend as $\mathrm{Cd}>\mathrm{Zn}>\mathrm{Cu}>\mathrm{Pb}>\mathrm{As}>\mathrm{Cr}$, which were dependent on the vegetable species. The estimated dietary intakes of $\mathrm{Cu}, \mathrm{Zn}, \mathrm{Pb}, \mathrm{Cr}$, As and $\mathrm{Cd}$ were far below the tolerable limits and the target hazard quotient (THQ) values were less than 1, which suggested that the health risks of heavy metals exposure through consuming vegetables were generally assumed to be safe.
\end{abstract}

Key words: heavy metals; soil; transfer factor; human health risk; wastewater irrigation

DOI: $10.1016 /$ S1001-0742(11)60833-4

\section{Introduction}

Wastewater irrigation has been practiced widespread for many years in the world, especially in the arid areas such as Germany, France, India (Ingwersen and Streck, 2006; Dère et al., 2006; Singh and Kumar, 2006) and China (Li et al., 2009), wastewater irragation creates both opportunities and problems in agricultural sector (Yadav et al., 2002). It provides important water resources and has the beneficial aspects of adding valuable plant nutrients and organic matter to soil (Liu et al., 2005). However, excessive accumulation of heavy metals in agricultural soil through wastewater irrigation may not only result in soil contamination, but also affect food quality and safety (Muchuweti et al., 2006). Dietary intake is the main route of exposure for most people, although inhalation can play an important role in very contaminated sites (Tripathi et al., 1997). Characteristically, vegetables can take up a lot of essential nutrients along with certain trace elements in a short period, therefore, the safety of vegetables is attracting more attention, especially the consumption of vegetables for Chinese residents is increasing greatly with the food structural adjustment in recent years (Liu et al., 2005). It is known that serious systemic health problems

\footnotetext{
* Corresponding author. E-mail: ygzhu@ @rcees.ac.cn
}

can develop as a result of excessive dietary intake of heavy metals such as $\mathrm{Cd}$ and $\mathrm{Pb}$ by human beings (Oliver, 1997). Although $\mathrm{Zn}$ and $\mathrm{Cu}$ are essential elements, their excessive concentration in food and feed plants are of great concern because of their toxicity to humans and animals (KabataPendias and Mukherjee, 2007). Heavy metal accumulation in plants depends upon plant species, and the efficiency of different plants in absorbing heavy metals is evaluated by either plant uptake or soil-to-plant transfer factors of the heavy metals (Rattan et al., 2005).

Thus, in order to assure the food safety, it is important to understand the heavy metals status in vegetables obtained from wastewater irrigation area. Suburban district between Beijing and Tianjin, has a 40-year history of wastewater or reclaimed water irrigation due to the water shortage and it is now an important vegetable production area for the region. Although a number of articles have been published on soil contamination in China (Liu et al., 2005; Wang et al., 2005; Khan et al., 2008), the situation has changed greatly with the change of irrigation water from wastewater to clean or reclaimed water. However, further research work is still needed regarding the soil and vegetable contamination, food safety and human health risks. The objective of this study was therefore to characterize the distribution and potential risk of selected heavy metals in soils and vegetables collected from suburban district 
between Beijing and Tianjin. This study can provide important information related with potential health risk via consumption of vegetables in Beijing-Tianjin city cluster areas.

\section{Materials and methods}

\subsection{Study area}

The study area is located in Beijing (Daxing District and Tongzhou District) and Tianjin (Wuqing District), China. The sampling sites were located along different rivers such as Feng River, Long River and Beiyun River, as shown in Fig. 1. This area has a continental monsoon climate, characterized by a wide seasonal variation in annual rainfall $(600 \mathrm{~mm})$, cold and dry winter, and hot and rainy summer. Being the capital of China, Beijing City is generating a huge amount of wastewater from domestic, commercial and industrial sectors. The wastewater irrigation commenced in the early 1960s and with the build of the Gaobeidian and Huangcun Wastewater Treatment Plant, reclaimed water has been used to irrigate the agricultural soils since 2000s. The soil types in this area are mainly fluvaquents. The cultivation plants are mainly wheat, corn, and vegetables (Liu et al., 2005).

\subsection{Sampling strategy and analysis of soil, vegetable and irrigated water}

Along the three rivers, 200 soil and plant samples were collected in September, 2009. At each site, a plot with a variety of vegetables including six vegetable species, Chinese cabbage (Brassica rapa pekinensis), leaf lettuce (Lactuca sativa), leek (Allium tuberosum), radish (Raphanus sativus), cauliflower (Brassica oleracea) and

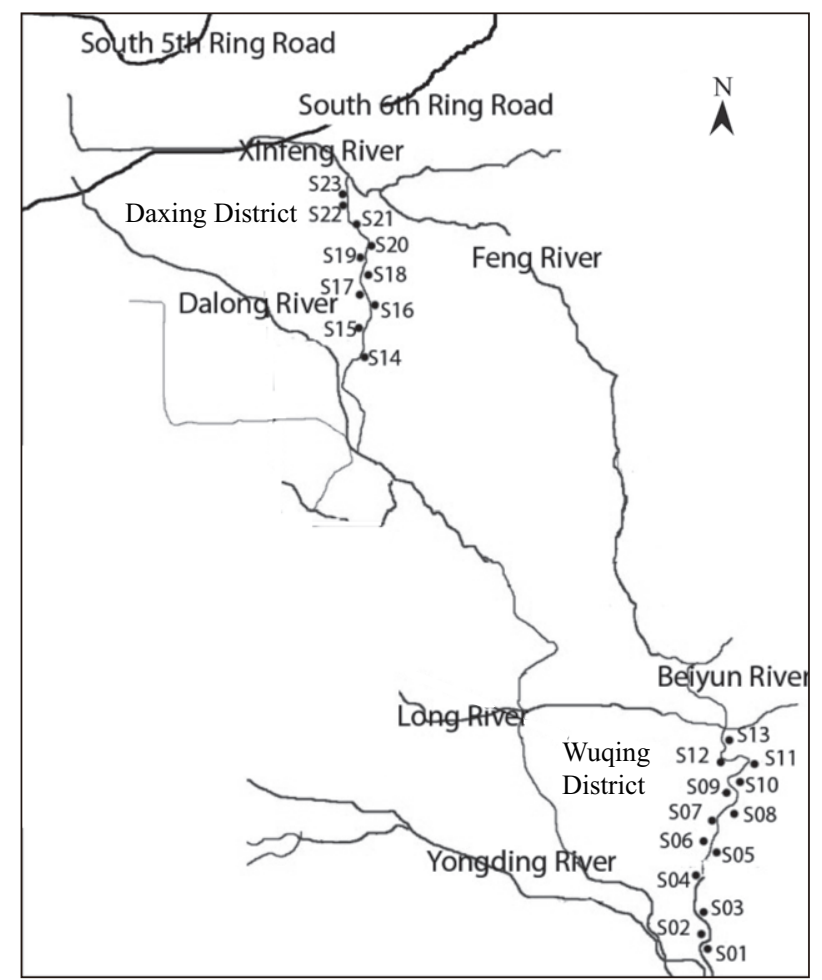

Fig. 1 Location map of the study area with sampling points. rape (Brassica campestris) were chosen and each kind of vegetable including the aerial parts, the roots and the associated surface soil were collected at the same time. About one kilogram of fresh soil samples $(0-20 \mathrm{~cm})$ was collected from five different locations $(200 \mathrm{~g}$ from each site) and thoroughly mixed to make a composite soil sample.

In laboratory, the vegetables were thoroughly washed with running tap water to remove airborne dust and soil particles and then with deionized water to remove the tap water. The root and aerial part of the vegetable samples were separated, dried at $55-60^{\circ} \mathrm{C}$ and pulverized to pass through a 40-mesh sieve. The soil samples were air-dried and then pass through a 60-mesh sieve. Sub-samples of soil were used to measure the physico-chemical properties according to standard procedures.

One gram dried soil was digested with 5-6 mL aqua regia, at $120^{\circ} \mathrm{C}$ for $1 \mathrm{hr}$, and then at $16^{\circ} \mathrm{C}$ for $3-4 \mathrm{hr}$. Then, 5-6 $\mathrm{mL}$ perchloric acid was added to continue digestion at $160^{\circ} \mathrm{C}$ for another $5-6 \mathrm{hr}$ until the soil became grey using a Foss digestion system. Plant samples were digested with $5 \mathrm{~mL}$ high-purity nitric acid at $160^{\circ} \mathrm{C}$ using a microwave oven (MARS5, CEM, USA). The digest was diluted to $50 \mathrm{~mL}$ using high-purity water. Determinations of $\mathrm{Cu}$, $\mathrm{Zn}, \mathrm{Pb}, \mathrm{Cr}, \mathrm{As}$ and $\mathrm{Cd}$ in all samples were performed using an inductively coupled plasma mass spectrometer (Plasma Quad 3, VG, England). The irrigated water was also collected and analyzed using the inductively coupled plasma mass spectrometer (Plasma Quad 3, VG, England) every month during 2009. The other soil properties including organic matter, available phosphorus, available potassium, $\mathrm{pH}$, were analyzed using corresponding methods. Soil pH was measured in 1:2.5 $(\mathrm{m} / \mathrm{V})$ soil:water using electronic $\mathrm{pH}$ meter (PB-10, Sartorius, China). Soil organic matter was determined by the $\mathrm{K}_{2} \mathrm{Cr}_{2} \mathrm{O}_{7}-\mathrm{H}_{2} \mathrm{SO}_{4}$ oxidation method. Available phosphorus and potassium were measured with sodium bicarbonate extraction and ammonium acetate lixiviation (Bao, 2000).

\subsection{Quality control}

The accuracy of analyses was checked with samples of tea and soil with certified concentrations (GBW07605, GBW07401, respectively, China National Center for Standard Materials) of selected heavy metals. The recovery of $\mathrm{Cu}, \mathrm{Zn}, \mathrm{Pb}, \mathrm{Cr}$, As and $\mathrm{Cd}$ were $98 \%, 101 \%, 96 \%$, $98 \%, 96 \%$ and $96 \%$, respectively. Repeated analyses of standard samples were regularly carried out to control reproducibility.

\subsection{Data analysis}

\subsubsection{Pollution load index}

The pollution load index (PLI) was based on the concentration factor of each heavy metal in the soil and defined by Tomlison et al. (1980). The concentration factor is the ratio obtained by dividing the concentration of each heavy metal in the soil by the base line or background values. In this study, PLI of each heavy metal was calculated by the comparison between the concentrations obtained in this study and the concentrations surveyed in 1999 to reveal the 
heavy metal contamination trends. A PLI value close to one indicates heavy metal loads near the background level, while values above one indicate soil pollution.

\subsubsection{Estimated daily intake of heavy metals}

The estimated daily intake (EDI) of heavy metals $(\mathrm{Cu}, \mathrm{Zn}$, $\mathrm{Pb}, \mathrm{Cr}, \mathrm{As}$ and $\mathrm{Cd}$ ) depended on both the heavy metal concentration in vegetables and the amount of consumption of the vegetable. The EDI of heavy metals for adults was determined by Eq. (1):

$\mathrm{EDI}=\frac{C_{\mathrm{m}} \times C_{\mathrm{f}} \times W_{\mathrm{f}}}{B_{\mathrm{w}}}$

where, $C_{\mathrm{m}}(\mathrm{mg} / \mathrm{kg}$, on fresh weight basis) represents the concentrations of heavy metals in vegetables. $C_{\mathrm{f}}$ represents conversion factor, 0.085 was used to convert fresh green vegetable weight to dry weight, as described by Rattan et al. (2005). $W_{\mathrm{f}}(\mathrm{kg} /($ person-day)) represents the daily average consumption of vegetables in this region; $B_{\mathrm{w}}(\mathrm{kg})$ is the body weight. The average daily vegetable intakes for adults and children were considered to be 0.345 and 0.232 $\mathrm{kg} /$ (person·day), respectively, while the average adult and child body weights were considered to be 63.9 and $32.7 \mathrm{~kg}$, respectively, as used in previous studies (Ge, 1996; Wang et al., 2005). The heavy metal intakes were compared with the tolerable daily intakes for heavy metals recommended by the World Health Organization (WHO, 1993).

\subsubsection{Target hazard quotient}

The target hazard quotient (THQ) was used to characterize the health risks of consuming vegetables by local inhabitants. The method was provided by US EPA (2007). THQ is expressed as the ratio of determined dose of a pollutant to a reference dose. If the ratio is less than 1 , the exposed population is unlikely to experience obvious adverse effects. The Eq. (2) is as follows:

$\mathrm{THQ}=\frac{\mathrm{EF}_{\mathrm{r}} \times \mathrm{ED} \times \mathrm{FI} \times C_{\mathrm{m}} \times 10^{-3}}{\mathrm{RfD} \times B_{\mathrm{w}} \times \mathrm{AT}}$

where, $\mathrm{EF}_{\mathrm{r}}$ (365 days/yr) is exposure frequency; ED is exposure duration (70 years); FI (g/(person-day)) is vegetable ingestion; $C_{\mathrm{m}}(\mathrm{mg} / \mathrm{kg}$ on fresh weight basis) is heavy metal concentration in vegetables; $\mathrm{RfD}(\mathrm{mg} /(\mathrm{kg} \cdot$ day $))$ is the oral reference dose; $B_{\mathrm{w}}$ is the average body weight, which are considered to be 63.9 and $32.7 \mathrm{~kg}$ for adult and child, respectively; AT is averaging time for noncarcinogens (365 days/year $\times$ number of exposure years, assuming 70 years in this study). $\mathrm{RfD}$ values for $\mathrm{Cu}, \mathrm{Zn}, \mathrm{Pb}$ and $\mathrm{Cd}$ were 0.04, 0.3, 0.004, $0.001 \mathrm{mg} /(\mathrm{kg} \cdot$ day), respectively (US EPA, 2007).

\section{Results and discussion}

\subsection{Concentrations of heavy metals in vegetable soils}

The range, median and mean values of six heavy metals in soils are shown in Table 1. The maximum concentrations of six heavy metals in vegetable soils were all below the maximum permitted levels in GB15618-1995 set by the Chinese Environmental Protecting Administration (CEPA, 1995) for soils in China, especially the concentration of $\mathrm{Pb}$ was greatly lower than the maximum permitted levels. The mean values of six metals were all higher than the background in Beijing (Chen et al., 2004), except $\mathrm{Pb}$ with mean value of $5.9 \mathrm{mg} / \mathrm{kg}$ was greatly lower than background of $24.6 \mathrm{mg} / \mathrm{kg}$. The average contents of five heavy metals including $\mathrm{Cu}, \mathrm{Zn}, \mathrm{Cr}$, As and $\mathrm{Cd}$ in this study were similar to the reported values of Chinese vegetable land soils (Zeng et al., 2008), except average $\mathrm{Pb}$ concentration $(5.86 \mathrm{mg} / \mathrm{kg}$ ) was much lower than the Chinese statistical average concentration $(29.5 \mathrm{mg} / \mathrm{kg})$. These results indicate that the soil in the study area can meet the quality for growing vegetables.

The analyzed heavy metal concentrations were greatly lower than those of Zhangshi Irrigation Area of Shenyang, China, where had a similar 30-year wastewater irrigation history (Li et al., 2009). The Cr concentrations (31.8-55.1 $\mathrm{mg} / \mathrm{kg}$ ) in this study were nearly half of that (58.0-126.2 $\mathrm{mg} / \mathrm{kg}$ ) in the suburban area of Shijiazhuang City irrigated with sewage, in the Hebei Province bordering on Beijing (Wang and Lin, 2003). The different water source could be the main reason since Zhangshi Irrigation Area and Shijiazhuang City were mainly from industrial wastewater, while Beijing-Tianjin area was mostly from domestic wastewater. The quality of reclaimed water used to irrigate the vegetable soils meets the standards for irrigation water quality (GB 5084-2005) and the values of $\mathrm{Cu}, \mathrm{Zn}, \mathrm{Pb}, \mathrm{Cr}$, As and $\mathrm{Cd}$ in irrigation water were very low (Table 2), which also supports the low metal concentration in this area. The $\mathrm{Cu}, \mathrm{Pb}, \mathrm{Cr}$, As and $\mathrm{Cd}$ concentrations in soils irrigated with wastewater for longer time (80 years) in Mexico City were much higher than those in BeijingTianjin city cluster. The low concentrations of metals may be partly due to the lower background values in this area (Liu et al., 2005).

The PLI values for $\mathrm{Cu}, \mathrm{Zn}, \mathrm{Pb}, \mathrm{Cr}$, As and $\mathrm{Cd}$ were calculated based on the background value of 1999 (Chen et al., 2004) with the values of $1.31,1.69,0.24,1.46$, 1.07 and 3.83 , respectively. PLI values in this study were lower than the reported PLI indices especially for $\mathrm{Pb}$, As and $\mathrm{Cu}$ (Khan et al., 2008; Liu et al., 2005). Compared

Table 1 Heavy metal concentrations in vegetable soils from Beijing-Tianjin city cluster $(n=98)$

\begin{tabular}{llllllll}
\hline Heavy metal & Min $(\mathrm{mg} / \mathrm{kg})$ & Max $(\mathrm{mg} / \mathrm{kg})$ & Median $(\mathrm{mg} / \mathrm{kg})$ & Mean $(\mathrm{mg} / \mathrm{kg})$ & Stdev $(\mathrm{mg} / \mathrm{kg})$ & $\mathrm{GB} 15618-1995(\mathrm{mg} / \mathrm{kg})$ & Background $(\mathrm{mg} / \mathrm{kg})$ \\
\hline $\mathrm{Cu}$ & 13.0 & 45.2 & 24.4 & 24.5 & 5.9 & 100 & 18.7 \\
$\mathrm{Zn}$ & 58.2 & 191.1 & 89.5 & 97.3 & 28.1 & 300 & 350 \\
$\mathrm{~Pb}$ & 3.2 & 8.7 & 5.8 & 5.9 & 1.2 & 250 & 2.3 \\
$\mathrm{Cr}$ & 31.8 & 55.1 & 43.7 & 43.5 & 5.3 & 0.6 & 7.1 \\
$\mathrm{As}$ & 4.7 & 9.8 & 7.6 & 7.6 & 0.02 & 0.12 \\
$\mathrm{Cd}$ & 0.20 & 0.18 & 0.11 & 0.46 & & 0.6 \\
\hline
\end{tabular}

Background values are cited from Chen et al., 2004. 
Table 2 Quarterly average of heavy metal concentrations in reclaimed water for irrigation $(n=24)$

\begin{tabular}{llllc}
\hline Heavy metal & 1st quarter & 2nd quarter & 3rd quarter & 4th quarter \\
\hline $\mathrm{Cu}(\mathrm{mg} / \mathrm{L})$ & 0.018 & 0.015 & 0.012 & 0.014 \\
$\mathrm{Zn}(\mathrm{mg} / \mathrm{L})$ & 0.367 & 0.253 & 0.078 & 0.078 \\
$\mathrm{~Pb}(\mathrm{mg} / \mathrm{L})$ & 0.045 & 0.036 & 0.041 & 0.047 \\
$\mathrm{Cr}(\mathrm{mg} / \mathrm{L})$ & 0.022 & 0.026 & 0.021 & 0.023 \\
$\mathrm{As}(\mu \mathrm{g} / \mathrm{L})$ & 0.51 & 0.66 & 0.58 & 0.42 \\
$\mathrm{Cd}(\mathrm{mg} / \mathrm{L})$ & 0.0056 & 0.0061 & 0.0052 & 0.2 \\
\hline
\end{tabular}

with the published data in this area (Khan et al., 2008; Liu et al., 2005), PLI values showed decreasing trends, which indicated alleviating pollution in this area after the wastewater irrigation was replaced by clean or reclaimed water. The PLI value for $\mathrm{Cd}$ was the highest, which was probably related to the presence of these heavy metals in the wastewater used for irrigation. Other possible heavy metal sources of vegetable soils include the application of solid waste, chemical fertilizer and organic fertilizer (Zeng et al., 2008).

The Pearson correlation coefficients were further calculated to illustrate the relationships between heavy metals and soil properties ( $\mathrm{pH}$, organic matter, available-P, available-K). $\mathrm{Cu}, \mathrm{Zn}$ showed significantly positive correlations with soil $\mathrm{Cr}\left(\mathrm{Cu}: r=0.746^{* *} ; \mathrm{Zn}: r=0.440^{* *}\right.$, $P<0.01)$. Their positive correlations suggested that heavy metal concentrations of $\mathrm{Cu}, \mathrm{Zn}$ and $\mathrm{Cr}$ in soil were probably controlled by similar processes (Chen et al., 2009). At the same time, $\mathrm{Cu}$ was also significantly correlated with soil available $\mathrm{P}$ and available $\mathrm{K}\left(r=0.493^{* *}, 0.482^{* *} ; P\right.$ $<0.01)$, Cd was significantly correlated with soil available $\mathrm{P}\left(r=0.400^{* *}, P<0.01\right)$. According to the survey in the sampling area, $800 \mathrm{~kg}$ organic fertilizers and $40 \mathrm{~kg} \mathrm{~N}$ $\mathrm{P}-\mathrm{K}$ composite fertilizers are used to increase the fresh vegetable production output per ha every year and the high available $P$ concentration in this area showed obvious imprints of fertilizers. Furthermore, wastewater is also an important resource of soil available $\mathrm{P}$ and available $\mathrm{K}$. Therefore, $\mathrm{Cu}, \mathrm{Zn}, \mathrm{Cr}$ and $\mathrm{Cd}$ may come from the additional phosphorus fertilizers and wastewater irrigation, which was agreed with the results investigated in the vegetable soil of Hangzhou, China (Chen et al., 2009). Other heavy metals such as $\mathrm{Pb}$, As and $\mathrm{Cd}$ showed no significant correlations with $\mathrm{Fe}$ and $\mathrm{Al}$, so $\mathrm{Pb}, \mathrm{As}$ and $\mathrm{Cd}$ were inferred that they came from human activities, for example wastewater irrigation. Atmospheric deposition is also regarded as one of the major sources of heavy metal contamination in urbanized areas, more and more studies have confirmed that atmospheric dry and wet deposition represent major pathways of anthropogenic inputs of heavy metals into the topsoil environment (Wong et al., 2003).

\subsection{Assessment of heavy metal concentration in vegeta- bles}

Concentrations of heavy metals in edible parts of vegetable including shoots of cabbage, Chinese cabbage, rape, leek, scallion and leaf lettuce, radish roots and cauliflower fruits from Beijing-Tianjin city cluster are shown in Fig. 2. The mean concentration of heavy metals in different kinds of vegetables in this study showed a wide range, with the value from 4.66 to $12.68 \mathrm{mg} / \mathrm{kg}$ for $\mathrm{Cu}, 27.11$ to 40.95 $\mathrm{mg} / \mathrm{kg}$ for $\mathrm{Zn}, 0.14$ to $0.93 \mathrm{mg} / \mathrm{kg}$ for $\mathrm{Pb}, 0.32$ to 1.36 $\mathrm{mg} / \mathrm{kg}$ for $\mathrm{Cr}, 0.17$ to $0.52 \mathrm{mg} / \mathrm{kg}$ for $\mathrm{As}, 0.04$ to 0.54 $\mathrm{mg} / \mathrm{kg}$ for $\mathrm{Cd}$ (based on dry weight).

The heavy metal concentrations showed an order of $\mathrm{Zn}$ $>\mathrm{Cu}>\mathrm{Cr}>\mathrm{Pb}>\mathrm{As}>\mathrm{Cd}$. In general, leafy vegetables such as cabbage, leaf lettuce, rape and leek accumulated higher heavy metal concentration in their edible parts than radish and cauliflower. This is due to the fact that leafy vegetables have high translocation rate and high transpiration rate as compared to other vegetables and also the transfer of heavy metals from root to stem and further to the fruit (vegetable) is longer which results in low accumulation than leafy vegetables (Muchuweti et al., 2006). This result was in agreement with the findings that leafy vegetables accumulate higher heavy metal concentrations in their edible parts than root and fruit vegetables in Cd-contaminated soils (Yang et al., 2009). Among the analyzed vegetables, the highest concentration of $\mathrm{Cu}$ was found in leek, $\mathrm{Zn}$ and $\mathrm{Cd}$ in rape, $\mathrm{Pb}, \mathrm{Cr}$ and As in leaf lettuce, but radish and cauliflower had very low heavy metal contents, which was significantly affected by vegetable species. Variations in heavy metal concentrations in different vegetables could be due to variable capabilities of plants to absorb and accumulate heavy metals (Pandey and Pandey, 2009), variations in growth period and growth rates (Moseholm et al., 1992). The results suggested that root and fruit vegetables appear to be relatively low accumulators of $\mathrm{Cd}, \mathrm{Pb}, \mathrm{Cr}$ and $\mathrm{As}$ in their edible parts, whereas leafy vegetables tend to accumulate more $\mathrm{Cd}, \mathrm{Pb}, \mathrm{Cr}$ and $\mathrm{As}$ in leaves, which was probably related to atmospheric deposition. Large surface area of leaves directly exposed to atmosphere and has been reported to accumulate sizable amount of air-borne $\mathrm{Cd}$, $\mathrm{Pb}$ and $\mathrm{Cr}$ (Pandey and Pandey, 2009). Moseholm et al. (1992) have observed a linear relationship between airborne $\mathrm{Pb}$ and its foliar concentrations in Kale and Italian rye grass. Hovmand et al. (1983) observed that $12 \%-60 \%$ of total heavy metals in the foliage of certain agricultural crops were due to atmospheric deposition. Atmospheric deposition has been identified as the principal source of heavy metals entering into plants and soils especially around urban-industrial areas.

The heavy metal contents of this study were compared with the recommended maximum intake levels set by China, Food and Agriculture Organization (FAO)/WHO and European Communities (EC) (Table 3). $\mathrm{Pb}, \mathrm{Cr}$, As and $\mathrm{Cd}$ concentrations in different parts of all vegetables were found to be greatly lower than the maximum levels, which indicated that all the vegetables were safe to enter 
the food chain. $\mathrm{Cu}$ and $\mathrm{Zn}$ were the essential elements for human body and therefore, they were not regulated in foods in China. However, FAO/WHO (2001) regulated the maximum level for $\mathrm{Cu}$ and $\mathrm{Zn}$ was 9.4 and 73.3 $\mathrm{mg} / \mathrm{kg}$ (based on fresh weight); EC (2001) or UK limits for $\mathrm{Cu}$ and $\mathrm{Zn}$ was 20 and $50 \mathrm{mg} / \mathrm{kg}$ (based on fresh weight), respectively. The average concentration for $\mathrm{Cu}$ and $\mathrm{Zn}$ was only 0.6 and $3.1 \mathrm{mg} / \mathrm{kg}$ (based on fresh weight) in vegetable edible parts in this study, which were greatly lower than the limits set by FAO/WHO, European Union (EU) or United Kingdom (UK) for $\mathrm{Cu}$ and $\mathrm{Zn}$, supposed that the conversation factor of fresh to dry weight was 0.085 (Ge et al., 1996). The lower concentration in vegetables suggested the deficiency of $\mathrm{Cu}$ and $\mathrm{Zn}$ should be paid much more attention in this area. It was reported the children for $\mathrm{Zn}$ deficiency were about $65 \%-86 \%$ in Beijing and the deficiency of $\mathrm{Zn}$ have posed a health risk for the residents, particularly for children in this area (Huang et al., 2006).

Heavy metal concentrations in vegetable edible parts in this study were lower than some previous reports from wastewater irrigated area. For example, the higher concentrations for $\mathrm{Cr}, \mathrm{Pb}, \mathrm{Cd}$ and $\mathrm{Cu}$ were reported in radish and cauliflower collected from treated wastewater irrigated suburban area of Titagarh (Gupta and Gupta, 1998). The concentrations of heavy metals ( $\mathrm{mg} / \mathrm{kg}$ dry weight) in leafy vegetables (Brassica species) ranged from 1.0 to 3.4 for $\mathrm{Cu}, 18$ to 201 for $\mathrm{Zn}, 0.7$ to 2.4 for $\mathrm{Cd}$, 0.7 to 5.4 for $\mathrm{Pb}$ and 1.5 to 6.6 for $\mathrm{Cr}$ in the City of Harare, and the concentrations in cauliflower (Brassica oleracea var. botrytis) were from 4.8 to 5.5 for $\mathrm{Cu}, 38.2$ to 41.8 for $\mathrm{Zn}$ in India, where wastewater were used for irrigating vegetables (Mapanda et al., 2007; Arora et al., 2008). The ranges of $\mathrm{Zn}, \mathrm{Cu}$ and $\mathrm{Cd}$ in this study were similar to the results of vegetables in this area, however, the concentrations of $\mathrm{Pb}$ and $\mathrm{Cr}$ were greatly lower than the results reported by Liu et al. (2005). Khan et al. (2008) reported higher results $(\mathrm{Cd} 0.36-0.94 \mathrm{mg} / \mathrm{kg}, \mathrm{Cr}$ $7.04-17.50 \mathrm{mg} / \mathrm{kg}, \mathrm{Cu} 9.60-15.40 \mathrm{mg} / \mathrm{kg}$, Zn 30.21-60.26 $\mathrm{mg} / \mathrm{kg}, \mathrm{Pb} 2.50-5.81 \mathrm{mg} / \mathrm{kg}$ ) in crops and vegetables from sewage irrigation agricultural soil of southeast of Beijing. The heavy metal concentration in vegetable edible parts of this study were lesser than the samples collected several years ago, which may be due to the improved irrigation water quality with the wastewater replacement by clean and reclaimed water.

\subsection{Transfer of heavy metals from soils to vegetables}

In order to assess the transfer of heavy metals from soil to vegetable, the transfer factor (TF) values of six heavy metals were calculated (Table 4). It defined as ratio of heavy metal concentration in vegetable (dry weight) to that in soil (dry weight) (Cui et al., 2004; Liu et al., 2005). The mean values of $\mathrm{TF}$ for $\mathrm{Cu}, \mathrm{Zn}, \mathrm{Pb}, \mathrm{Cr}, \mathrm{As}$ and Cd were $0.32,0.39,0.11,0.02,0.05,1.47$, with a range of $0.02-1.18,0.02-1.06,0.00-0.50,0.00-0.10,0.01-0.87$ and $0.06-4.69$, respectively. The TF values were greatly lower than the results reported by Liu et al. (2005), which maybe related to the low plant concentrations in this study.

The mean TF values of six heavy metals showed the trend as $\mathrm{Cd}>\mathrm{Zn}>\mathrm{Cu}>\mathrm{Pb}>\mathrm{As}>\mathrm{Cr}$. $\mathrm{Cd}$ had the highest $\mathrm{TF}$ and $\mathrm{Cr}$ had the lowest in this study, which was in agreement with the translocation trend reported by Khan et al. (2008) and Liu et al. (2005) in the southeast of Beijing agricultural soils. Similar trend was also found in vegetables from wastewater irrigated soils by Mapanda et al. (2007) at Mukuvisi, Zimbabwe. Cd with the highest $\mathrm{TF}$ in this study suggested its accumulation in soil and vegetables should be paid more attention although the $\mathrm{Cd}$ concentration in soils and vegetable edible parts still meets the maximum permitted levels (CEPA, 1995; WHO, 1993).

The TF of different heavy metals were dependent on the

Table 3 Recommended maximum levels and heavy metal concentrations in this study for vegetables (mg/kg, fresh weight)

\begin{tabular}{|c|c|c|c|c|c|c|}
\hline $\mathrm{Cu}$ & $\mathrm{Zn}$ & $\mathrm{Pb}$ & $\mathrm{Cr}$ & As & $\mathrm{Cd}$ & Heavy metal \\
\hline NR & NR & $\begin{array}{l}0.3 \text { root and leafy } \\
0.1 \text { others }\end{array}$ & 0.5 & 0.05 & $\begin{array}{l}0.1 \text { root } \\
0.2 \text { leafy } \\
0.05 \text { others }\end{array}$ & CMH, 2005 \\
\hline 9.4 & 73.3 & 0.3 & 2.3 & 0.05 & $\begin{array}{l}0.2 \text { leafy } \\
0.05 \text { others }\end{array}$ & FAO/WHO, 2001 \\
\hline 20 & 50 & 0.3 & NR & NR & $\begin{array}{l}0.1 \text { root } \\
0.2 \text { leafy } \\
0.05 \text { others }\end{array}$ & $\mathrm{EC}, 2001$ \\
\hline 0.6 & 3.1 & 0.04 & 0.05 & 0.03 & 0.02 & This study \\
\hline
\end{tabular}

NR: not recommended.

Table 4 Transfer factors of heavy metals in vegetables from Beijing-Tianjin city cluster

\begin{tabular}{llllrr}
\hline Vegetables & $\mathrm{Cu}$ & $\mathrm{Zn}$ & $\mathrm{Pb}$ & $\mathrm{Cr}$ & $\mathrm{Cd}$ \\
\hline Cabbage $(n=5)$ & $0.23-0.53$ & $0.28-0.39$ & $0.07-0.29$ & $0.02-0.06$ & $0.02-0.05$ \\
Chinese cabbage $(n=33)$ & $0.15-0.37$ & $0.16-0.50$ & $0.07-0.22$ & $0.00-0.07$ & $0.47-4.69$ \\
Rape $(n=6)$ & $0.24-0.35$ & $0.29-0.56$ & $0.05-0.14$ & $0.01-0.02$ & $0.03-0.09$ \\
Leek $(n=6)$ & $0.28-1.18$ & $0.21-0.55$ & $0.06-0.21$ & $0.01-0.06$ & $0.07-0.10$ \\
Scallion $(n=5)$ & $0.02-0.44$ & $0.02-1.06$ & $0.01-0.50$ & $0.00-0.07$ & $0.07-3.91$ \\
Leaf lettuce $(n=4)$ & $0.29-0.53$ & $0.29-0.58$ & $0.09-0.25$ & $0.00-0.07$ & $0.05-0.11$ \\
Radish $(n=19)$ & $0.15-0.28$ & $0.15-0.73$ & $0.00-0.06$ & $0.00-0.02$ & $0.02-0.05$ \\
Cauliflower $(n=18)$ & $0.20-0.75$ & $0.24-0.78$ & $0.00-0.19$ & $0.00-0.10$ & $0.18-0.64$ \\
\hline
\end{tabular}



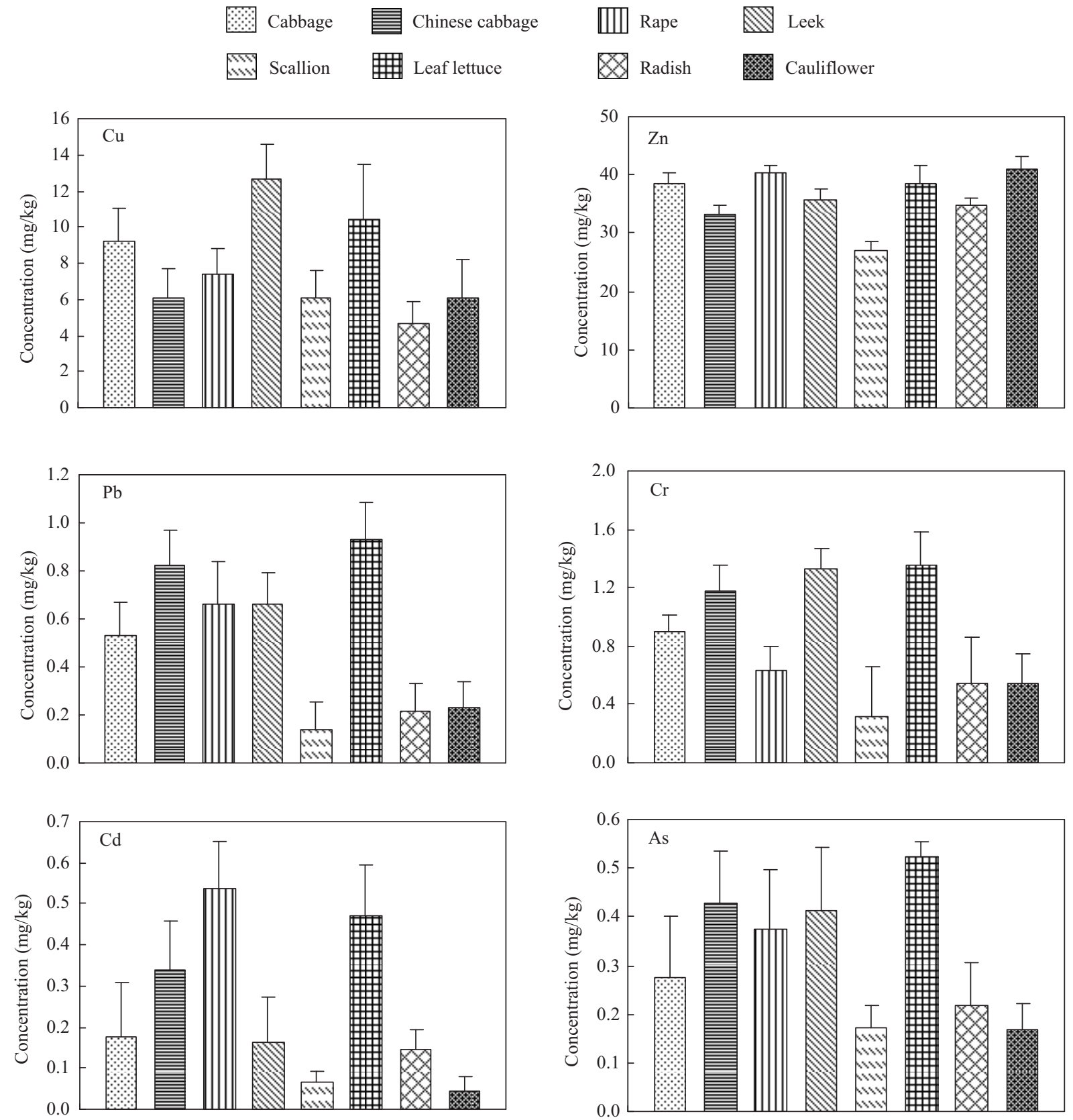

Fig. 2 Mean concentration (on dry weight basis) of heavy metals in vegetable edible parts, cabbage $(n=5)$, Chinese cabbage $(n=33)$, rape $(n=6)$, leek $(n=6)$, scallion $(n=5)$, leaf lettuce $(n=4)$, radish $(n=19)$ and cauliflower $(n=18)$.

vegetable type and species. The highest and lowest TF for $\mathrm{Cd}$ were found in leaf lettuce and cauliflower, respectively. The highest and lowest TF for $\mathrm{Cu}$ was observed in leek and radish, respectively. Scallion had highest TF for $\mathrm{Zn}$ and $\mathrm{As}$. However, $\mathrm{TF}$ for $\mathrm{Pb}$ and $\mathrm{Cr}$ were similar among different kinds of vegetables. As a whole, cauliflower as a kind of fruit vegetable had relatively lower TF for $\mathrm{Cd}, \mathrm{Pb}$, As and $\mathrm{Cr}$, compared to the leafy vegetables. Therefore, cauliflower was recommended to cultivate considering the food safety in this area.

\subsection{Health risk assessment of heavy metals through food chain}

According to the average vegetable consumption, the estimated daily intake of heavy metals (EDI) through the food chain is given in Table 5, for both adults and children. The highest intakes of $\mathrm{Cu}, \mathrm{Zn}, \mathrm{Pb}, \mathrm{Cr}, \mathrm{As}$, and $\mathrm{Cd}$ were from the consumption of leek, cauliflower, leaf lettuce, leek, leaf lettuce and rape, respectively, for both adults and children. The estimated dietary intakes of $\mathrm{Cu}, \mathrm{Zn}, \mathrm{Pb}, \mathrm{Cr}$, As and $\mathrm{Cd}$ were far below the tolerable limits. Oral reference doses (RfD) for $\mathrm{Cu}, \mathrm{Zn}, \mathrm{Pb}, \mathrm{Cr}$, As and $\mathrm{Cd}$ are 0.04, 0.3, $0.0035,1.5,0.0003$ and $0.001 \mathrm{mg} /(\mathrm{kg} \cdot$ day $)$, respectively (US EPA, 2007). The RfD is regarded as an estimate of a daily exposure to the human population that is likely to be without an appreciable risk of deleterious effects during a lifetime (US EPA, 2007). The daily heavy metal intake for both adults and children through vegetable consumption in this study was less than RfD limit set by the US EPA, Integrated Risk Information System (IRIS).

In order to assess the health risk of heavy metals in vegetables, it is essential to estimate the level of exposure 
Table 5 EDI and THQ for individual heavy metals caused by consumption of different kinds of vegetables

\begin{tabular}{|c|c|c|c|c|c|c|c|c|}
\hline Vegetable & Type & & $\mathrm{Cu}$ & $\mathrm{Zn}$ & $\mathrm{Pb}$ & $\mathrm{Cr}$ & As & $\mathrm{Cd}$ \\
\hline \multirow[t]{4}{*}{ Chinese cabbage $(n=33)$} & \multirow[t]{2}{*}{ Adults } & EDI & $3.2 \mathrm{E}-3$ & $1.7 \mathrm{E}-2$ & $4.3 \mathrm{E}-4$ & $6.2 \mathrm{E}-4$ & $2.2 \mathrm{E}-4$ & $1.8 \mathrm{E}-4$ \\
\hline & & THQ & $8.0 \mathrm{E}-2$ & $5.8 \mathrm{E}-2$ & $1.2 \mathrm{E}-1$ & 4.1E-4 & $7.5 \mathrm{E}-1$ & $1.8 \mathrm{E}-1$ \\
\hline & \multirow[t]{2}{*}{ Children } & EDI & $3.7 \mathrm{E}-3$ & $2.0 \mathrm{E}-2$ & 4.9E-4 & 7.1E-4 & $2.6 \mathrm{E}-4$ & $2.0 \mathrm{E}-4$ \\
\hline & & THQ & $9.2 \mathrm{E}-2$ & $6.7 \mathrm{E}-2$ & $1.4 \mathrm{E}-1$ & $4.7 \mathrm{E}-4$ & $8.6 \mathrm{E}-1$ & $2.0 \mathrm{E}-1$ \\
\hline \multirow[t]{4}{*}{ Leaf lettuce $(n=4)$} & \multirow[t]{2}{*}{ Adults } & EDI & $5.4 \mathrm{E}-3$ & $2.0 \mathrm{E}-2$ & $4.9 \mathrm{E}-4$ & $7.1 \mathrm{E}-4$ & $2.7 \mathrm{E}-4$ & $2.5 \mathrm{E}-4$ \\
\hline & & THQ & $1.4 \mathrm{E}-1$ & $6.7 \mathrm{E}-2$ & $1.4 \mathrm{E}-1$ & 4.7E-4 & $9.1 \mathrm{E}-1$ & $2.5 \mathrm{E}-1$ \\
\hline & \multirow[t]{2}{*}{ Children } & EDI & $5.4 \mathrm{E}-3$ & $2.0 \mathrm{E}-2$ & 4.9E-4 & 7.1E-4 & $2.7 \mathrm{E}-4$ & $2.5 \mathrm{E}-4$ \\
\hline & & THQ & $1.4 \mathrm{E}-1$ & $6.7 \mathrm{E}-2$ & $1.4 \mathrm{E}-1$ & 4.7E-4 & $9.1 \mathrm{E}-1$ & $2.5 \mathrm{E}-1$ \\
\hline \multirow[t]{4}{*}{ Leek $(n=6)$} & \multirow[t]{2}{*}{ Adults } & EDI & $6.7 \mathrm{E}-3$ & $1.9 \mathrm{E}-2$ & $3.5 \mathrm{E}-4$ & $7.0 \mathrm{E}-4$ & $2.2 \mathrm{E}-4$ & $8.5 \mathrm{E}-5$ \\
\hline & & THQ & $1.7 \mathrm{E}-1$ & $6.3 \mathrm{E}-2$ & $9.9 \mathrm{E}-2$ & 4.7E-4 & 7.2E-1 & 8.5E-2 \\
\hline & \multirow[t]{2}{*}{ Children } & EDI & $7.6 \mathrm{E}-3$ & $2.2 \mathrm{E}-2$ & $4.0 \mathrm{E}-4$ & $8.0 \mathrm{E}-4$ & $2.5 \mathrm{E}-4$ & $9.8 \mathrm{E}-5$ \\
\hline & & THQ & $1.9 \mathrm{E}-1$ & 7.2E-2 & $1.1 \mathrm{E}-1$ & $5.3 \mathrm{E}-4$ & 8.3E-1 & $9.8 \mathrm{E}-2$ \\
\hline \multirow[t]{4}{*}{ Cabbage $(n=5)$} & \multirow[t]{2}{*}{ Adults } & EDI & $4.8 \mathrm{E}-3$ & $2.0 \mathrm{E}-2$ & $2.8 \mathrm{E}-4$ & 4.7E-4 & $1.5 \mathrm{E}-4$ & 9.3E-5 \\
\hline & & THQ & $1.2 \mathrm{E}-1$ & $6.7 \mathrm{E}-2$ & 7.9E-2 & $3.1 \mathrm{E}-4$ & $4.8 \mathrm{E}-1$ & $9.3 \mathrm{E}-2$ \\
\hline & \multirow[t]{2}{*}{ Children } & EDI & $5.6 \mathrm{E}-3$ & $2.3 \mathrm{E}-2$ & $3.2 \mathrm{E}-4$ & $5.4 \mathrm{E}-4$ & $1.7 \mathrm{E}-4$ & $1.1 \mathrm{E}-4$ \\
\hline & & THQ & $1.4 \mathrm{E}-1$ & 7.7E-2 & $9.1 \mathrm{E}-2$ & $3.6 \mathrm{E}-4$ & $5.6 \mathrm{E}-1$ & $1.1 \mathrm{E}-1$ \\
\hline \multirow[t]{4}{*}{ Rape $(n=6)$} & \multirow[t]{2}{*}{ Adults } & EDI & $3.9 \mathrm{E}-3$ & $2.1 \mathrm{E}-2$ & $3.5 \mathrm{E}-4$ & $3.3 \mathrm{E}-4$ & $2.0 \mathrm{E}-4$ & $2.8 \mathrm{E}-4$ \\
\hline & & THQ & 9.7E-2 & 7.1E-2 & 9.9E-2 & $2.2 \mathrm{E}-4$ & $6.5 \mathrm{E}-1$ & $2.8 \mathrm{E}-1$ \\
\hline & \multirow[t]{2}{*}{ Children } & EDI & $4.5 \mathrm{E}-3$ & $2.4 \mathrm{E}-2$ & 4.0E-4 & $3.8 \mathrm{E}-4$ & 2.3E-4 & $3.2 \mathrm{E}-4$ \\
\hline & & THQ & $1.1 \mathrm{E}-1$ & 8.1E-2 & $1.1 \mathrm{E}-1$ & $2.5 \mathrm{E}-4$ & $7.5 \mathrm{E}-1$ & $3.2 \mathrm{E}-1$ \\
\hline \multirow[t]{4}{*}{ Scallion $(n=5)$} & \multirow[t]{2}{*}{ Adults } & EDI & $3.2 \mathrm{E}-3$ & $1.4 \mathrm{E}-2$ & $7.1 \mathrm{E}-5$ & $1.7 \mathrm{E}-4$ & $9.0 \mathrm{E}-5$ & $3.4 \mathrm{E}-5$ \\
\hline & & THQ & 7.9E-2 & 4.7E-2 & $2.0 \mathrm{E}-2$ & $1.1 \mathrm{E}-4$ & $3.0 \mathrm{E}-1$ & $3.4 \mathrm{E}-2$ \\
\hline & \multirow[t]{2}{*}{ Children } & EDI & $3.7 \mathrm{E}-3$ & $1.6 \mathrm{E}-2$ & $8.2 \mathrm{E}-5$ & $1.9 \mathrm{E}-4$ & $1.0 \mathrm{E}-4$ & $3.9 \mathrm{E}-5$ \\
\hline & & THQ & $9.1 \mathrm{E}-2$ & $5.5 \mathrm{E}-2$ & $2.3 \mathrm{E}-2$ & $1.3 \mathrm{E}-4$ & $3.5 \mathrm{E}-1$ & $3.9 \mathrm{E}-2$ \\
\hline \multirow[t]{4}{*}{ Radish root $(n=19)$} & \multirow[t]{2}{*}{ Adults } & EDI & $2.4 \mathrm{E}-3$ & $1.8 \mathrm{E}-2$ & $1.1 \mathrm{E}-4$ & $2.8 \mathrm{E}-4$ & $1.1 \mathrm{E}-4$ & 7.6E-5 \\
\hline & & THQ & $6.1 \mathrm{E}-2$ & $6.1 \mathrm{E}-2$ & $3.3 \mathrm{E}-2$ & $1.9 \mathrm{E}-4$ & $3.8 \mathrm{E}-1$ & 7.6E-2 \\
\hline & \multirow[t]{2}{*}{ Children } & EDI & $2.8 \mathrm{E}-3$ & $2.1 \mathrm{E}-2$ & $1.3 \mathrm{E}-4$ & $3.3 \mathrm{E}-4$ & $1.3 \mathrm{E}-4$ & 8.7E-5 \\
\hline & & THQ & 7.0E-2 & 7.0E-2 & $3.8 \mathrm{E}-2$ & $2.2 \mathrm{E}-4$ & $4.4 \mathrm{E}-1$ & 8.7E-2 \\
\hline \multirow[t]{4}{*}{ Cauliflower fruit $(n=18)$} & \multirow[t]{2}{*}{ Adults } & EDI & $3.2 \mathrm{E}-3$ & 2.1E-2 & $1.2 \mathrm{E}-4$ & $2.8 \mathrm{E}-4$ & $8.9 \mathrm{E}-5$ & $2.2 \mathrm{E}-5$ \\
\hline & & THQ & 8.0E-2 & 7.2E-2 & $3.4 \mathrm{E}-2$ & $1.9 \mathrm{E}-4$ & $3.0 \mathrm{E}-1$ & $2.2 \mathrm{E}-2$ \\
\hline & \multirow{2}{*}{ Children } & EDI & $3.7 \mathrm{E}-3$ & $2.5 \mathrm{E}-2$ & $1.4 \mathrm{E}-4$ & 3.3E-4 & $1.0 \mathrm{E}-4$ & $2.5 \mathrm{E}-5$ \\
\hline & & THQ & $9.2 \mathrm{E}-2$ & 8.2E-2 & $4.0 \mathrm{E}-2$ & 2.2E-4 & $3.4 \mathrm{E}-1$ & $2.5 \mathrm{E}-2$ \\
\hline
\end{tabular}

by quantifying the routes of exposure of heavy metals to the target organisms. Food chain through vegetables consumption is one of the most important exposure pathways of heavy metals to humans (Muchuweti et al., 2006). In the study area, the vegetables and other foodstuffs produced are mostly sold in the local urban market and consumed by the local residents. Therefore, the average heavy metal concentrations of vegetables were used for calculation of the THQ. The THQ of heavy metals through the consumption of vegetables for both adults and children is given in Table 5. The THQ of $\mathrm{Cu}, \mathrm{Zn}, \mathrm{Pb}, \mathrm{Cr}$, As and $\mathrm{Cd}$ ranged from 0.061 to $0.170,0.047$ to $0.072,0.020$ to $0.14,0.00011$ to $0.00047,0.30$ to 0.91 , and 0.022 to 0.280 , respectively for adults, while ranged from 0.07 to 0.19 , 0.055 to $0.082,0.023$ to $0.140,0.00013$ to $0.00053,0.340$ to 0.910 , and 0.025 to 0.320 , respectively for children. The THQ of heavy metals decreased in the order of As $>\mathrm{Cd}>\mathrm{Cu}>\mathrm{Pb}>\mathrm{Zn}>\mathrm{Cr}$. The THQ $<1$ means the exposed population is assumed to be safe. The THQ values calculated in this study were all less than 1 which suggested the health risks of heavy metal exposure through food chain was generally assumed to be safe. The health risk assessment results in this study were consistent with the results reported by Khan et al. (2008) and the THQ values were greatly lower than those from wastewater irrigated soils along Musi River, India (Sridhara et al., 2008) and Pakistan (Jan et al., 2010).

The findings of this study regarding EDI and THQ suggest that the consumption of vegetables grown in wastewater irrigated soils is nearly free of risks for the local population, but there are also other sources of heavy metal exposures such as dust inhalation, dermal contact and ingestion (for children) of metal-contaminated soils, which were not included in this study.

\section{Conclusions}

The concentrations of $\mathrm{Cu}, \mathrm{Zn}, \mathrm{Pb}, \mathrm{Cr}$, As and $\mathrm{Cd}$ in soil and vegetable from long term wastewater irrigation area of Beijing-Tianjin city cluster were lower than the maximum permitted levels set by CEPA (1995), Chinese State Standard (GB 2762-2005), and the limits set by FAO/WHO and EU. The PLI values showed a decreasing trend compared with the previously published data in this area indicating that the soil quality has improved since the wastewater irrigation was replaced by clean or reclaimed water. The mean TF of six heavy metals showed the trend as $\mathrm{Cd}>\mathrm{Zn}>\mathrm{Cu}>\mathrm{Pb}>\mathrm{As}>\mathrm{Cr}$. Cauliflower with relatively lower $\mathrm{TF}$ for $\mathrm{Cd}, \mathrm{Pb}$, As and $\mathrm{Cr}$ was suitable for cultivating in this area. The potential health risks of heavy metal exposure from vegetable consuming were considered low based on the estimated daily intake (EDI) of heavy metals and the target hazard quotient (THQ).

\section{Acknowledgments}

This work was supported by the Major Projects of Knowledge Innovation Program of Chinese Academy of Sciences (No. KZCX2-YW-Q02-05) and the Beijing Science and 
Technology Program (No. D101105046410004).

\section{References}

Arora M, Kiran B, Rani S, Rani A, Kaur B, Mittal N, 2008. Heavy metal accumulation in vegetables irrigated with water from different sources. Food Chemistry, 111(4): 811-815.

Bao S D, 2000. Analysis of Soil Characteristics (3rd ed.). China Agricultural Press, Beijing. 81-106.

CEPA, 1995. Environmental quality standard for soils. Chinese Environmental Protection Administration, China. GB15618-1995.

$\mathrm{CMH}, 2005$. Maximum levels of contaminants in foods. Chinese Ministry of Health. GB2762-2005.

Chen T, Liu X M, Li X, Zhao K L, Zhang J B, Xu J M et al., 2009. Heavy metal sources identification and sampling uncertainty analysis in a field-scale vegetable soil of Hangzhou, China. Environmental Pollution, 157(3): 1003-1010.

Chen T B, Zheng Y M, Chen H, Zhen G D, 2004. Background concentrations of soil heavy metals in Beijing. Environmental Science, 25(1): 117-122.

Cui Y J, Zhu Y G, Zhai R H, Chen D Y, Huang Y Z, Qui $\mathrm{Y}$ et al., 2004. Transfer of metals from soil to vegetables in an area near a smelter in Nanning, China. Environment International, 30(6): 785-791.

Dère C, Lamy I, van Oort F, Baize D, Cornu S, 2006. Trace metal inputs reconstitution and migration assessment in a sandy Luvisol after 100 years of massive irrigation with raw wastewaters. Comptes Rendus Geoscience, 338(8): 565573.

EC, 2001. Commission Regulation. No.466/2001. Setting maximum levels for certain contaminants in foodstuffs. Official Journal of the European Communities, 16/03/2001.

FAO/WHO, 2001. Report on the 32nd Session of the Codex Committee on Food Additives and Contaminants, In: Joint FAO/WHO Food Standard Programme Codex Alimentarius Commission, 24th Session. Geneva, Switzerland. 2-7 July.

Ge K Y, Zhai F Y, Yan H C, 1996. The Dietary and Nutritional Status of Chinese Population - Volume 1: National Nutrition Survey in 1992. People's Medical Publishing House, Beijing. 126-228.

Gupta U C, Gupta S C, 1998. Trace element toxicity relationships to crop production and livestock and human health: implications for management. Common Soil Science and Plant Analysis, 29(11-14): 1491-1522.

Hovmand M F, Tjell J C, Mosbaek H, 1983. Plant uptake of airborne cadmium. Environmental Pollution, 30(1): 27-38.

Huang Z C, Song B, Chen T B, Zheng Y M, Yang J, 2006. A survey of zinc concentrations in vegetables and soils in Beijing and their health risk. Geographical Research, 25(3): 439-447.

Ingwersen J, Streck T, 2006. Modeling the environmental fate of cadmium in a large wastewater irrigation area Journal of Environmental Quality, 35(5): 1702-1714.

Jan F A, Ishaq M, Khan S, Ihsanullah I, Ahmad I, Shakirullah M, 2010. A comparative study of human health risks via consumption of food crops grown on wastewater irrigated soil (Peshawar) and relatively clean water irrigated soil (lower Dir). Journal of Hazardous Materials, 179(1-3): 612-621.

Kabata-Pendias A, Mukherjee A B, 2007. Trace elements from soil to human. Springer-Verlag, New York.

Khan S, Cao Q, Zheng Y M, Huang Y Z, Zhu Y G, 2008. Health risks of heavy metals in contaminated soils and food crops irrigated with wastewater in Beijing, China. Environmental Pollution, 152(3): 686-692.

Li P J, Wang X, Allinson G, Li X J, Xiong X Z, 2009. Risk assessment of heavy metals in soil previously irrigated with industrial wastewater in Shenyang, China. Journal of Hazardous Materials, 161(1): 516-521.

Liu W H, Zhao J Z, Ouyang Z Y, Söderlund L, Liu G H, 2005. Impacts of sewage irrigation on heavy metal distribution and contamination in Beijing, China. Environment International, 31(6): 805-812.

Mapanda F, Mangwayana E N, Nyamangara J, Giller K E, 2007. Uptake of heavy metals by vegetables irrigated using wastewater and the subsequent risks in Harare, Zimbabwe. Physics and Chemistry of the Earth, 32(15-18): 1399-1405.

Moseholm L, Larsen E H, Andersen B, Nielsen M M, 1992. Atmospheric deposition of trace elements around point sources and human health risk assessment. I: impact zones near a source of lead emissions. Science of the Total Environment, 126(3): 243-262.

Muchuweti M, Birkett J W, Chinyanga E, Zvauya R, Scrimshaw $M D$ et al, 2006. Heavy metal content of vegetables irrigated with mixtures of wastewater and sewage sludge in Zimbabwe: implications for human health. Agriculture Ecosystem and Environment, 112(1): 41-48.

Oliver M A, 1997. Soil and human health: a review. European Journal of Soil Science, 48(4): 573-592.

Pandey J, Pandey U, 2009. Accumulation of heavy metals in dietary vegetables and cultivated soil horizon in organic farming system in relation to atmospheric deposition in a seasonally dry tropical region of India. Environmental Monitoring and Assessment, 148(1-4): 61-74.

Rattan R K, Datta S P, Chhonkar P K, Suribabu K, Singh A K, 2005. Long-term impact of irrigation with sewage effluents on heavy metal content in soils, crops and groundwater - a case study. Agriculture Ecosystem and Environment, 109(34): $310-322$.

Singh S, Kumar M, 2006. Heavy metal load of soil, water and vegetables in peri-urban Delhi. Environmental Monitoring and Assessment, 120(1-3): 71-79.

Sridhara C N, Kamala C T, Raj D S S, 2008. Assessing risk of heavy metals from consuming food grown on sewage irrigated soils and food chain transfer. Ecotoxicology and Environmental Safety, 69(3): 513-524.

Tomlison D L, Wilson J G, Harris C R, Jeffrey D W, 1980. Problems in the assessment of heavy-metal levels in estuaries and the formation of a pollution index. Helgoländer Meeresuntersuchungen, 33(1-4): 566-575.

Tripathi R M, Raghunath R, Krishnamoorthy T M, 1997. Dietary intake of heavy metals in Bombay City, India. Science of the Total Environment, 208(3): 149-159.

US EPA, 2007. United States, Environmental Protection Agency, Integrated Risk Information System. http://www.epa.gov/iris/subst.

Wang G L, Lin W J, 2003. Contamination of soil from sewage irrigation and its remediation. Journal of Agro-Environmental Science, 22(2): 163-166.

Wang X L, Sato T, Xing B S, Tao S, 2005. Health risks of heavy metals to the general public in Tianjin, China via consumption of vegetables and fish. Science of the Total Environment, 350(1-3): 28-37.

WHO (World Heath Organization), 1993. Evaluation of certain food additives and contaminants. In: 41st Report of the Joint FAO/WHO Expert Committee on Food Additives. Technical Report Series. WHO, Geneva. 
Wong C S C, Li X D, Zhang G, Qi S H, Peng X Z, 2003. Atmospheric deposition of heavy metals in the Pearl River Delta, China. Atmospheric Environment, 37(6): 767-776.

Yadav R K, Goyal B, Sharma R K, Dubey S K, Minhas P S, 2002. Post-irrigation impact of domestic sewage effluent on composition of soils, crops and ground water - a case study. Environment International, 28(6): 481-486.
Yang Y, Zhang F S, Li H F, Jiang R F, 2009. Accumulation of cadmium in the edible parts of six vegetable species grown in Cd-contaminated soils. Journal of Environmental Management, 90(2): 1117-1122.

Zeng X B, Li L F, Mei X R, 2008. Heavy metal content in Chinese vegetable plantation land soils and related source analysis. Agricultural Sciences in China, 7(9): 1115-1126. 